\title{
Incidence and health risk assessment of grazing animals due to toxic metal residues (Cd and Mn) in Sahiwal, Sargodha
}

\author{
Maria Ghazzal ${ }^{1}$, Zafar Iqbal Khan ${ }^{1 *}$, Kafeel Ahmad ${ }^{1}$, Naunain \\ Mehmood $^{2}$, Shehzadi Mahpara ${ }^{3}$, Muhammad Nadeem ${ }^{4}$, Mudasra \\ Munir $^{1}$, Kinza Wajid ${ }^{1}$, Muhammad Sohail ${ }^{1}$, Ifra Saleem Malik ${ }^{1}$, Asma \\ Ashfaq ${ }^{1}$, Humayun Bashir ${ }^{1}$, Mubeen Akhtar ${ }^{1}$ and Pervaiz Akhter ${ }^{1}$ \\ 1. Department of Botany, University of Sargodha, Sargodha-Pakistan \\ 2. Department of Zoology, University of Sargodha, Sargodha-Pakistan \\ 3. Department of Plant Breeding and Genetics, Ghazi University, D.G. Khan-Pakistan \\ 4. Institute of Food Science and Nutrition, University of Sargodha, Sargodha-Pakistan \\ *Corresponding author's email:zafar.khan@uos.edu.pk \\ Citation \\ Maria Ghazzal, Zafar Iqbal Khan, Kafeel Ahmad, Naunain Mehmood, Shehzadi Mahpara, Muhammad Nadeem, \\ Mudasra Munir, Kinza Wajid, Muhammad Sohail, Ifra Saleem Malik, Asma Ashfaq, Humayun Bashir, Mubeen \\ Akhtar and Pervaiz Akhter. Incidence and health risk assessment of grazing animals due to toxic metal residues $(\mathrm{Cd}$ \\ and $\mathrm{Mn}$ ) in Sahiwal, Sargodha. Pure and Applied Biology. Vol. 9, Issue 1, pp872-883. \\ http://dx.doi.org/10.19045/bspab.2020.90092
}

\begin{tabular}{llll}
\hline \hline Received: 12/09/2019 & Revised: 01/12/2019 & Accepted: 13/12/2019 & Online First: 01/01/2020 \\
\hline
\end{tabular}

\section{Abstract}

Ecological contamination due to toxic chemicals is the major issue. Present research was conducted to find out the concentration of $\mathrm{Cd}$ and $\mathrm{Mn}$ in fodder soil and blood. Five sites of Tehsil Sahiwal of District Sargodha were selected for research where mostly contaminated water was used for irrigation. Pollution load index as well as health risk index was also studied. The results show that cadmium and manganese exceeded the permissible limit of $\mathrm{Cd}(0.2)$ and $\mathrm{Mn}(500) \mathrm{mg} / \mathrm{kg}$ suggested by FAO/WHO. Enrichment factor showed lower values as compared to standard. Higher values were observed for Mn at site-V 3.09 $\mathrm{mg} / \mathrm{kg}$ for summer samples of Zea mays and lower Trifoilum alaxandrium $1.17 \mathrm{mg} / \mathrm{kg}$, while for Cd higher values were observed for Zea mays $2.80 \mathrm{mg} / \mathrm{kg}$ and lower for Trifolium alaxandrium $0.20 \mathrm{mg} / \mathrm{kg}$ for during winter season.

Keywords: Cadmium; Health risk index; Manganese; Pollution load index

\section{Introduction}

The distribution of different characters of soil affects the grouping of metals in soils [1]. The uptake of overwhelming metals in fodders is impacted by numerous factors, atmosphere, humidity conditions, centralizations of the irresistible nature of soil, chemicals in soils, and intensity of development of plants at season of collection $[2,3]$. Plants absorbing metals in high level may result in great risk. They can deplete essential nutrient from human body and decreased immunity [4].

Study of dumpsites had shown that depending on the age location and contents soil contains different concentration of toxic 
chemicals [5-7]. Since of their solidness, metals may enter natural compartments, in a few cases, numerous years underlying testimony contamination of soil and water frameworks may likewise emerge from decomposition of arranged item [8]. Toxic chemicals which have been found to cause adverse effect on the root system of forage plants include $\mathrm{Zn}, \mathrm{Cu}, \mathrm{Pb}$ and $\mathrm{Hg}$ [19].

Roots are the fundamental organs of plants through which they absorb overwhelming metals from the soil. In metal free soil, vegetables developed on overwhelming metal polluted soils gather higher measures of metals than those developed in unpolluted soils [4, 10-13]. Overwhelming chemicals are constant in the earth and are liable to bioaccumulate in natural pecking orders. They are effortlessly collected in eatable in fodder, as compared to other crops [14]. They stay in eatable segment of leaves as opposed to grains of nourishment. Metals were added in fodder through roots and stored in aerial parts [15].

The purpose of present investigation was to analyze $\mathrm{Cd}, \mathrm{Mn}$ concentration in soil and various varieties of forage crops irrigated with wastewater, in relation to the requirements of buffaloes consuming those forages".

\section{Materials and methods Study site}

Research was conducted in the Tehsil Sahiwal of Sargodha division. Sahiwal is situated 37 kilometers from Sargodha Jhang road and is almost $5 \mathrm{~km}$ away from river Jhelum. Samples were taken from five sites. All these sites receive wastewater irrigation (Figure 1).

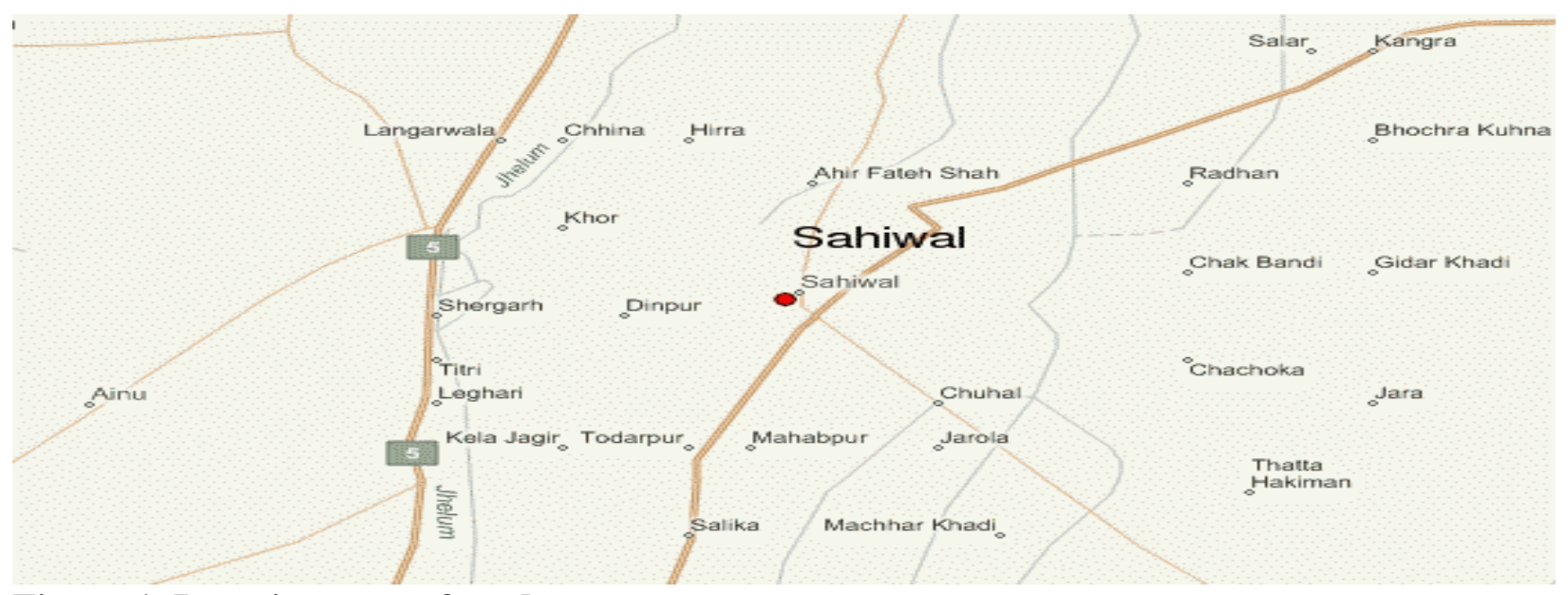

Figure 1. Location map of study area

\section{Sample collection}

Samples along with (3 replicates) were collected. Soil and plant samples were taken, sealed in label paper bags. Forage sample contained three plant species Trifolium alexandrinum (Barseem) Zea mays L. (corn) Sorghum bicolor (Millet). All the forage and soil samples were dried in air and in an oven at $72^{\circ} \mathrm{C}$ for 48 hours to attain constant dry weight. Fifteen samples of buffalo blood were taken along with three replicates. After collection samples were centrifuged at 2500 $\mathrm{rpm}$ for 2 minutes to obtain plasma. The serum was transported to the laboratory in a cool box and kept frozen at $-20^{\circ} \mathrm{C}$ before investigation.

\section{Sample preparation for analysis}

Wet digestion method was used for digestion. $\mathrm{HNO}_{3}(2 \mathrm{ml})$ and $\mathrm{H}_{2} \mathrm{O}_{2}(4 \mathrm{ml})$ were used for digestion. 2 grams of soil and forage were taken and heated for 30min and then cooled. $\mathrm{H}_{2} \mathrm{O}_{2}$ were added in this sample until a 
colorless solution was obtained. Distilled water was used to make the volume $50 \mathrm{ml}$. Determination of $\mathrm{Zn}$ and $\mathrm{Pb}$ concentration was performed with the help of an atomic absorption spectrophotometer (Model \# AA6300, Shimadzu, Japan) equipped with a graphite furnace (AA6300\&GFAEXi7i).

\section{Statistical analysis}

SPSS was used to find analysis of variance and correlation of data.

Bio concentration factor (BCF)

Bio concentration factor from soil to forage was calculated using Microsoft excel by the following formula:

$\mathrm{BCF}=$ mean concentration of metal in fodder/ mean concentration of metal in soil

Enrichment Factor (EF)

It was determined by Buat-Menard and Chesselet [16].

$\mathrm{EF}=[\mathrm{M}]_{\text {fodder }} /[\mathrm{M}]_{\text {Soil }} /[\mathrm{M}]_{\text {fodder S }} /[\mathrm{M}]_{\text {soil S }}$

Pollution load index (PLI)

Pollution load index was calculated by the formula Liu et al. [17].

$\mathrm{PLI}=$ metal concentration in examined soil/metal concentration in reference soil".

Daily intake of metal (DIM)

DIM was calculated by following Sajjad et al. [18].

$\mathrm{DIM}=\mathrm{C}_{\text {metal }} \times$ Dfood intake $\times \mathrm{C}_{\text {conversion factor }} /$ $B_{\text {average weight }}$

\section{Health risk index (HRI)}

Health risk index value can be calculated by daily intake of metal and oral reference dose (RfD) Cui et al., [19].

Health risk index $(\mathrm{HRI})=\mathrm{DIM} / \mathrm{RfD}$ ”

\section{Results}

\section{Analysis of variance}

Blood samples of all the sites had nonsignificant $(>0.001)$ values (Table 1$)$.

Concentration of $\mathrm{Cd}$ in soil samples

Higher concentration of $\mathrm{Cd}$ was found at site$\mathrm{V} 0.60$ to $0.783 \mathrm{mg} / \mathrm{kg}$ and lower at site-I 0.10 to $0.233 \mathrm{mg} / \mathrm{kg}$ in summer season. In winter, highest concentration was found at site-V (0.90-0.925) and the lowest at site-I (0.142$0.58)$. Higher concentration was found during winter for Z. mays (Figure 2).

Table 1. Analysis of variance for $\mathrm{Cd}$ concentration in soil, fodder and blood

\begin{tabular}{|c|c|c|c|c|c|}
\hline Sample & Site-I & Site-II & Site-III & Site-IV & Site-V \\
\hline Summer Soil & $0.000 \mathrm{~ns}$ & $0.002^{* * *}$ & $0.000 \mathrm{~ns}$ & $0.002^{* *}$ & $0.003^{* *}$ \\
\hline Winter soil & $0.006^{* * *}$ & $0.001^{* * *}$ & $0.001 * *$ & $0.003^{* *}$ & $0.002^{*}$ \\
\hline Summer Fodder & $0.006^{* * *}$ & $0.001^{* * *}$ & $0.001^{*}$ & $0.003^{* *}$ & $0.002^{* *}$ \\
\hline Winter Fodder & $0.013^{* *}$ & $0.002^{* * *}$ & $0.000^{* *}$ & $0.009^{* * *}$ & $0.001^{* * *}$ \\
\hline Summer blood & $0.003^{* * *}$ & $0.001 * * *$ & $0.001 * * *$ & $0.002^{* * *}$ & $0.001^{* * *}$ \\
\hline Winter blood & $0.000 \mathrm{~ns}$ & $0.000 \mathrm{~ns}$ & $0.001 * * *$ & $0.000 \mathrm{~ns}$ & $0.000 \mathrm{~ns}$ \\
\hline
\end{tabular}

$*, * *, * * *=$ Significant at $0.05,0.01$ and $0.001, \mathrm{~ns}=$ non-significant

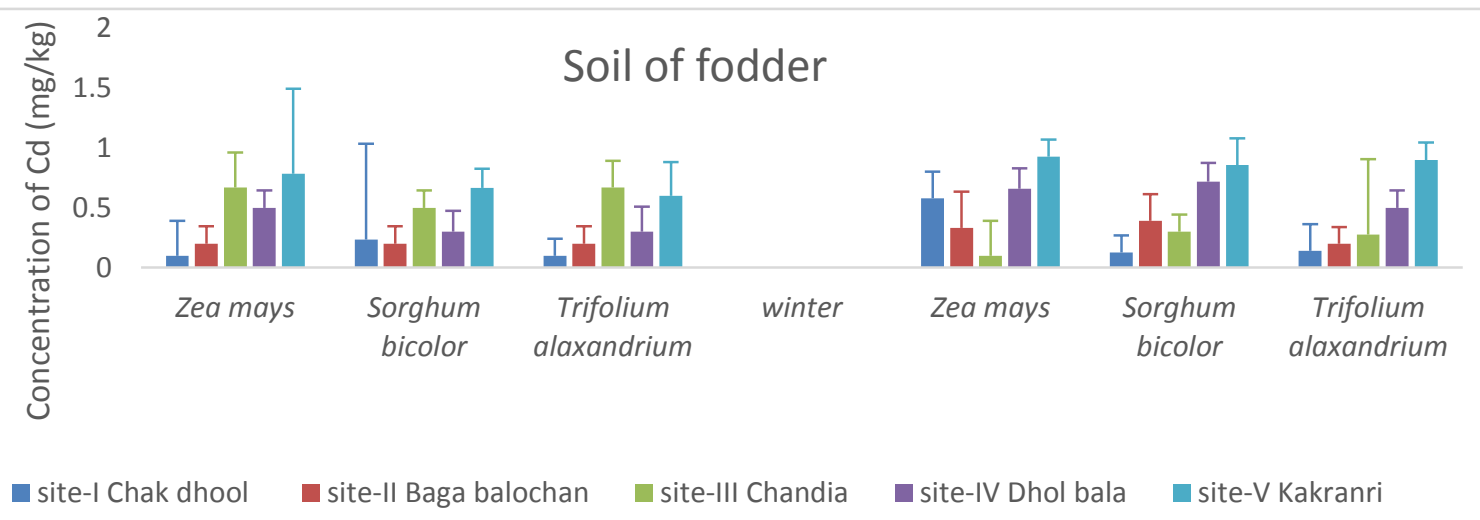

Figure 2. Fluctuations in mean concentration of $\mathrm{Cd}$ in soil at different sites during summer and winter season 
Concentration of $\mathbf{C d}$ in fodder samples A relatively high concentration of $\mathrm{Cd}$ was noticed at site- $\mathrm{V}$ in summer that ranged from 0.85 to 0.925 . In winter, high concentration ranged from 0.094 to 0.10 and low 0.06 to 0.07 (Figure 3).

\section{Concentration of $\mathbf{C d}$ in blood samples}

It was noted that blood samples collected at site-Vin summer had more $\mathrm{Cd}$ values
$(0.2125-0.70)$ than the samples collected in winter season (0.2017-0.2350). Less contaminated in both seasons was site-I and range of values were $0.1050-0.1325$ and $0.120-0.1433$. Between seasons, the most accumulation was found at site- $\mathrm{V}$ in winter (Figure 4).

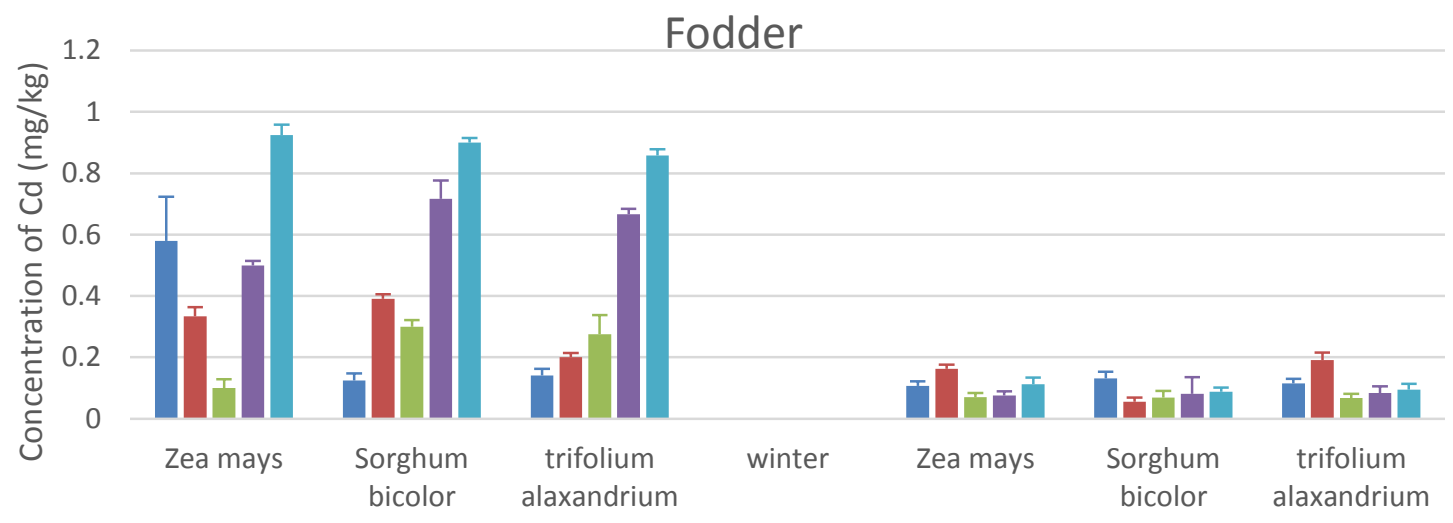

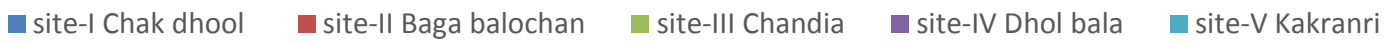

Figure 3. Fluctuations in mean concentration of $\mathrm{Cd}$ in fodder samples at different sites during summer and winter season

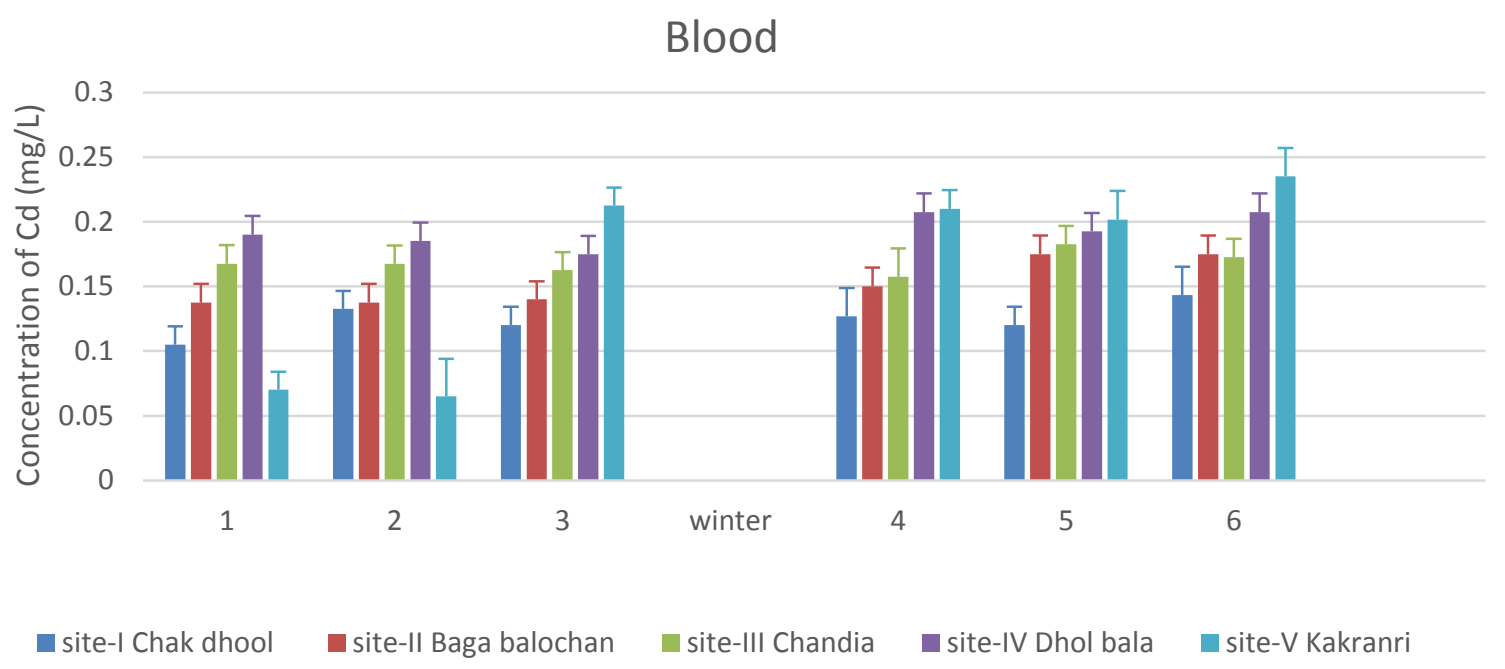

Figure 4. Fluctuations in mean concentration of $\mathrm{Cd}$ in blood samples at different sites during summer and winter season 


\section{Correlation coefficients of fodder samples}

Positive and non-significant correlation was observed for all of three forage crops from soil to fodder samples of summer and negative and non-significant correlation was observed for fodder-blood samples and soil to fodder samples in winter. Trifolium alaxandrium had significant correlation for fodder-blood (Table 2).

\section{Pollution load index}

The PLI of Cd showed higher values for siteV. All the values are lower than 1 which indicated that soil was less contaminated in present investigation (Table 3).

\section{Bio concentration factor}

Bioconcentration factor values for $\mathrm{Cd}$ in fodder samples were higher at site-IV and site- $\mathrm{V}$. The lowest BCF value was observed at site-I (Table 4).

\section{Daily intake of metal}

Site-V had higher DIM values as compared to other sites. Site-I and Site-2 had lower value of intake at daily basis (Table 5).

\section{Health risk index}

Health risk index for $\mathrm{Cd}$ was found to be higher than the limit set by WHO [20]. SiteV had higher values than all others (Table 6).

\section{Enrichment factor}

High EF value was found at site-V. Lower EF was observed at site-I. These observations revealed that site- $\mathrm{V}$ had higher risk as compared to other sites (Table 7).

\section{Manganese (Mn)}

Some of the samples at site- $\mathrm{V}$ of soil and blood had non-significant values ( $p>0.001)$. Other samples had significant value $(p>0.05)$ (Table 8).

\section{Concentration of $\mathrm{Mn}$ in soil sample}

Higher Mn values ranged from 2.41 to 2.40 at site- $\mathrm{V}$ and lower values ranged from 1.16 to 1.205 at site-I in summer season. In winter season, higher Mn values ranged from 1.405 to 1.45 ) at site- $\mathrm{V}$ and lower values ranged from 1.17 to 1.1925 at site-I (Figure 5).

\section{Concentration of $\mathrm{Mn}$ in fodder samples}

The result showed that higher $\mathrm{Mn}$ values ranged from 3.5425 to 3.555 at site- $\mathrm{V}$ and lower values from 1.407 to 1.440 at site-I in summer season. In winter season, higher Mn values ranged from 2.52 to 2.536 and lower from 1.35 to 1.4416 (Figure 6).

\section{Concentration of $\mathrm{Mn}$ in blood samples}

High Mn concentrations in blood samples were found at site-V (1.485-1.9625) and lower values at site-I (1.3116-1.1050) in summer season. In winter season, higher Mn concentrations were found at site-V (1.63506.130) and lower values at site-I (0.26500.3575) (Figure 7).

Correlation coefficients of fodder samples Significant correlation was observed for soil to fodder and fodder to blood samples for Z.mays and also for Sorghum bicolor and Trifolium alaxandrium from soil to fodder. Positive and non-significant correlation was observed for soil to fodder and also for fodder to blood in winter (Table 9).

\section{Pollution load index}

Winter samples of $S$. bicolor showed high PLI at site-V. Summer samples of $T$. alaxandrium showed lowest value of PLI at site-II. All the values were lower than 1 indicated that soil was not much contaminated (Table 3).

\section{Bio-concentration factor}

All the values were higher than 1 (Table 4).

\section{Daily intake of metal}

According to WHO 1994 its tolerable range is from $0.5-5 \mathrm{mg} / \mathrm{kg} /$ day all the values in present investigation was within range (Table 5).

\section{Health risk index}

All the values were higher than HRI was higher oral reference dose for $\mathrm{Mn}$ $(0.041 \mathrm{mg} / \mathrm{kg})$ (Table 6).

\section{Enrichment factor}

Enrichment factor was high for all samples in present investigation. Highest enrichment was observed at site- $\mathrm{V}$ in both seasons and 
lowest for site-I in both seasons for all the samples (Table 7).

Table 2. Correlation between soil-fodder-blood for $\mathrm{Cd}$

\begin{tabular}{|c|c|c|c|c|c|c|}
\hline \multicolumn{7}{|c|}{ Correlation Coefficient } \\
\hline & \multicolumn{2}{|c|}{ Z. mays } & \multicolumn{2}{c|}{ S. bicolor } & \multicolumn{2}{c|}{ T. alexandrinum } \\
\hline & Soil-fodder & Fodder-Blood & Soil-Fodder & $\begin{array}{c}\text { Fodder- } \\
\text { blood }\end{array}$ & $\begin{array}{c}\text { Soil- } \\
\text { fodder }\end{array}$ & $\begin{array}{c}\text { Fodder- } \\
\text { blood }\end{array}$ \\
\hline Summer & 0.847 & -0.420 & .592 & -0.393 & 0.483 & $0.965^{* *}$ \\
\hline Winter & 0.027 & -0.307 & -0.313 & -0.723 & -0.384 & -0.292 \\
\hline
\end{tabular}

** Correlation is significant at the 0.01 level (2-tailed)

Table 3. Pollution load index for $\mathrm{Cd}$ and Mn

\begin{tabular}{|c|c|c|c|c|c|c|}
\hline \multicolumn{7}{|c|}{ Pollution load index } \\
\hline Site & \multicolumn{2}{|c|}{ Z. mays } & \multicolumn{2}{|c|}{ S. bicolor } & \multicolumn{2}{|c|}{ T. alexandrinum } \\
\hline & Summer & Winter & Summer & Winter & Summer & Winter \\
\hline \multicolumn{7}{|c|}{ Cd } \\
\hline Site-I & 0.067 & 0.38 & 0.156 & 0.083 & 0.0671 & 0.095 \\
\hline Site-II & 0.1342 & 0.2234 & 0.1342 & 0.263 & 0.134 & 0.134 \\
\hline Site-III & 0.449 & 0.067 & 0.33 & 0.201 & 0.449 & 0.184 \\
\hline Site-IV & 0.33 & 0.44 & 0.201 & 0.480 & 0.20 & 0.33 \\
\hline Site-V & 0.52 & 0.620 & 0.447 & 0.57 & 0.402 & 0.64 \\
\hline \multicolumn{7}{|c|}{ Mn } \\
\hline Site-I & 0.025 & 0.025 & 0.0259 & 0.025 & 0.0259 & 0.025 \\
\hline Site-II & 0.0257 & 0.0271 & 0.0259 & 0.0265 & 0.0268 & 0.026 \\
\hline Site-III & 0.026 & 0.027 & 0.028 & 0.027 & 0.028 & 0.028 \\
\hline Site-IV & 0.027 & 0.028 & 0.028 & 0.029 & 0.028 & 0.030 \\
\hline Site-V & 0.051 & 0.030 & 0.051 & 0.030 & 0.051 & 0.031 \\
\hline
\end{tabular}

Table 4. Bio concentration factor for $\mathrm{Cd}$ and $\mathrm{Mn}$

\begin{tabular}{|c|c|c|c|c|c|c|}
\hline \multicolumn{7}{|c|}{ Bioconcentration factor } \\
\hline Site & \multicolumn{2}{|c|}{ Z. mays } & \multicolumn{2}{|c|}{ S. bicolor } & \multicolumn{2}{|c|}{ T. alexandrinum } \\
\hline & Summer & Winter & Summer & Winter & Summer & Winter \\
\hline \multicolumn{7}{|c|}{ Cd } \\
\hline Site-I & 5.8 & 0.185 & 0.536 & 1.04 & 1.41 & 0.8 \\
\hline Site-II & 1.665 & 0.48 & 1.955 & 0.14 & 1 & 0.9 \\
\hline Site-III & 0.149 & 0.7 & 0.6 & 0.23 & 0.41 & 0.24 \\
\hline Site-IV & 1 & 0.11 & 2.39 & 0.112 & 2.22 & 0.166 \\
\hline Site-V & 1.18 & 0.120 & 1.349 & 0.101 & 1.43 & 0.10 \\
\hline \multicolumn{7}{|c|}{ Mn } \\
\hline Site-I & 1.17 & 1.232 & 1.15 & 1.203 & 1.18 & 1.14 \\
\hline Site-II & 1.18 & 1.140 & 1.18 & 1.16 & 1.13 & 1.170 \\
\hline Site-III & 1.20 & 1.15 & 1.11 & 1.13 & 1.104 & 1.10 \\
\hline Site-IV & 1.93 & 1.13 & 1.89 & 1.089 & 1.47 & 1.04 \\
\hline Site-V & 1.87 & 1.80 & 1.47 & 1.79 & 1.47 & 1.73 \\
\hline
\end{tabular}


Table 5. Daily intake of metal for Cd and Mn

\begin{tabular}{|c|c|c|c|c|c|c|}
\hline \multicolumn{7}{|c|}{ Daily intake of metal } \\
\hline Site & \multicolumn{2}{|c|}{ Z. mays } & \multicolumn{2}{|c|}{ S. bicolor } & \multicolumn{2}{|c|}{ T. alexandrinum } \\
\hline & Summer & Winter & Summer & Winter & Summer & Winter \\
\hline \multicolumn{7}{|c|}{ Cd } \\
\hline Site-I & 0.001760 & 0.00038 & 0.00043 & 0.00384 & 0.000397 & 0.000349 \\
\hline Site-II & 0.001011 & 0.001187 & 0.000607 & 0.00049 & 0.000167 & 0.000582 \\
\hline Site-III & 0.000304 & 0.000911 & 0.000835 & 0.000213 & 0.00021 & 0.000205 \\
\hline Site-IV & 0.001518 & 0.002177 & 0.002025 & 0.000228 & 0.000245 & 0.000253 \\
\hline Site-V & 0.002808 & 0.002732 & 0.00260 & 0.000339 & 0.000266 & 0.000286 \\
\hline \multicolumn{7}{|c|}{ Mn } \\
\hline Site-I & 0.0507 & 0.051 & 0.0502 & 0.05 & 0.051 & 0.048 \\
\hline Site-II & 0.051 & 0.051 & 0.051 & 0.051 & 0.050 & 0.051 \\
\hline Site-III & 0.052 & 0.052 & 0.052 & 0.052 & 0.052 & 0.052 \\
\hline Site-IV & 0.090 & 0.053 & 0.090 & 0.05 & 0.089 & 0.052 \\
\hline Site-V & 0.12 & 0.090 & 0.126 & 0.090 & 0.126 & 0.09 \\
\hline
\end{tabular}

Table 6. Health risk index for $\mathrm{Cd}$ and Mn

\begin{tabular}{|c|c|c|c|c|c|c|}
\hline \multicolumn{7}{|c|}{ Health risk index } \\
\hline Site & \multicolumn{2}{|c|}{ Z. mays } & \multicolumn{2}{|c|}{ S. bicolor } & \multicolumn{2}{|c|}{ T. alexandrinum } \\
\hline & Summer & Winter & Summer & Winter & Summer & Winter \\
\hline \multicolumn{7}{|c|}{ Cd } \\
\hline Site-I & 0.33 & 0.37 & 0.42 & 0.39 & 0.34 & 0.34 \\
\hline Site-II & 0.22 & 0.24 & 0.60 & 0.16 & 0.58 & 0.56 \\
\hline Site-III & 0.30 & 0.90 & 0.83 & 0.21 & 0.21 & 0.20 \\
\hline Site-IV & 1.51 & 0.26 & 0.28 & 1.01 & 1.18 & 0.25 \\
\hline Site-V & 2.80 & 2.73 & 2.60 & 2.17 & 2.01 & 1.76 \\
\hline \multicolumn{7}{|c|}{ Mn } \\
\hline Site-I & 1.23 & 1.25 & 1.22 & 1.25 & 1.25 & 1.17 \\
\hline Site-II & 1.24 & 1.25 & 1.24 & 1.25 & 1.24 & 1.25 \\
\hline Site-III & 1.29 & 1.28 & 1.27 & 1.27 & 1.27 & 1.26 \\
\hline Site-IV & 2.20 & 1.31 & 2.21 & 1.29 & 2.17 & 1.29 \\
\hline Site-V & 3.09 & 2.20 & 3.096 & 2.20 & 3.08 & 2.19 \\
\hline
\end{tabular}

Table 7. Enrichment factor for $\mathrm{Cd}$ and $\mathrm{Mn}$

\begin{tabular}{|c|c|c|c|c|c|c|}
\hline \multicolumn{7}{|c|}{ Enrichment factor } \\
\hline Site & \multicolumn{2}{|c|}{ Z. mays } & \multicolumn{2}{|c|}{ S. bicolor } & \multicolumn{2}{|c|}{ T. alexandrinum } \\
\hline & Summer & Winter & Summer & Winter & Summer & Winter \\
\hline \multicolumn{7}{|c|}{ Cd } \\
\hline Site-I & 0.0016 & 0.0024 & 0.0072 & 0.014 & 0.0013 & 0.0014 \\
\hline Site-II & 0.0015 & 0.0065 & 0.00151 & 0.0018 & 0.013 & 0.0128 \\
\hline Site-III & 0.002 & 0.0093 & 0.008 & 0.0030 & 0.005 & 0.0032 \\
\hline Site-IV & 0.013 & 0.022 & 0.032 & 0.0262 & 0.029 & 0.0022 \\
\hline Site-V & 0.015 & 0.077 & 0.018 & 0.018 & 0.019 & 0.0108 \\
\hline \multicolumn{7}{|c|}{ Mn } \\
\hline Site-I & 5.04 & 5.27 & 4.95 & 5.14 & 5.07 & 4.86 \\
\hline Site-II & 5.07 & 4.87 & 5.05 & 4.98 & 4.84 & 5.006 \\
\hline Site-III & 5.14 & 4.95 & 4.78 & 4.86 & 4.72 & 4.73 \\
\hline
\end{tabular}




\begin{tabular}{|c|c|c|c|c|c|c|}
\hline Site-IV & 6.314 & 4.84 & 6.31 & 4.66 & 6.31 & 4.468 \\
\hline Site-V & 8.09 & 7.72 & 8.007 & 7.6 & 8.28 & 7.434 \\
\hline
\end{tabular}

Table 8. Analysis of variance for Mn concentration in soil, fodder and blood samples at different sites

\begin{tabular}{|c|c|c|c|c|c|}
\hline & Site-I & Site-II & Site-III & Site-IV & Site-V \\
\hline Summer Soil & $0.003^{* * *}$ & $0.002^{* * *}$ & $0.007^{* * *}$ & $0.001^{* * *}$ & $0.000 \mathrm{~ns}$ \\
\hline Winter soil & $0.000^{* * *}$ & $0.001^{* * *}$ & $0.002^{* * *}$ & $0.006^{* * *}$ & $0.002^{*}$ \\
\hline Summer Fodder & $0.000^{* * *}$ & $0.001^{* * *}$ & $0.009^{* * *}$ & $0.000^{*}$ & $0.004^{* *}$ \\
\hline Winter Fodder & $0.000^{*}$ & $0.000^{* * *}$ & $0.001^{*}$ & $0.002^{*}$ & $0.031^{* * *}$ \\
\hline Summer blood & $0.001^{* * *}$ & $0.051^{* * *}$ & $2.712^{* * *}$ & $0.030^{* * *}$ & $0.003^{* * *}$ \\
\hline Winter blood & $0.697 \mathrm{~ns}$ & $0.985^{* * *}$ & $0.012^{* * *}$ & $0.012^{* * *}$ & $20.521 \mathrm{~ns}$ \\
\hline
\end{tabular}

$*, * *, * * *=$ Significant at $0.05,0.01$ and $0.001, \mathrm{~ns}=$ non-significant

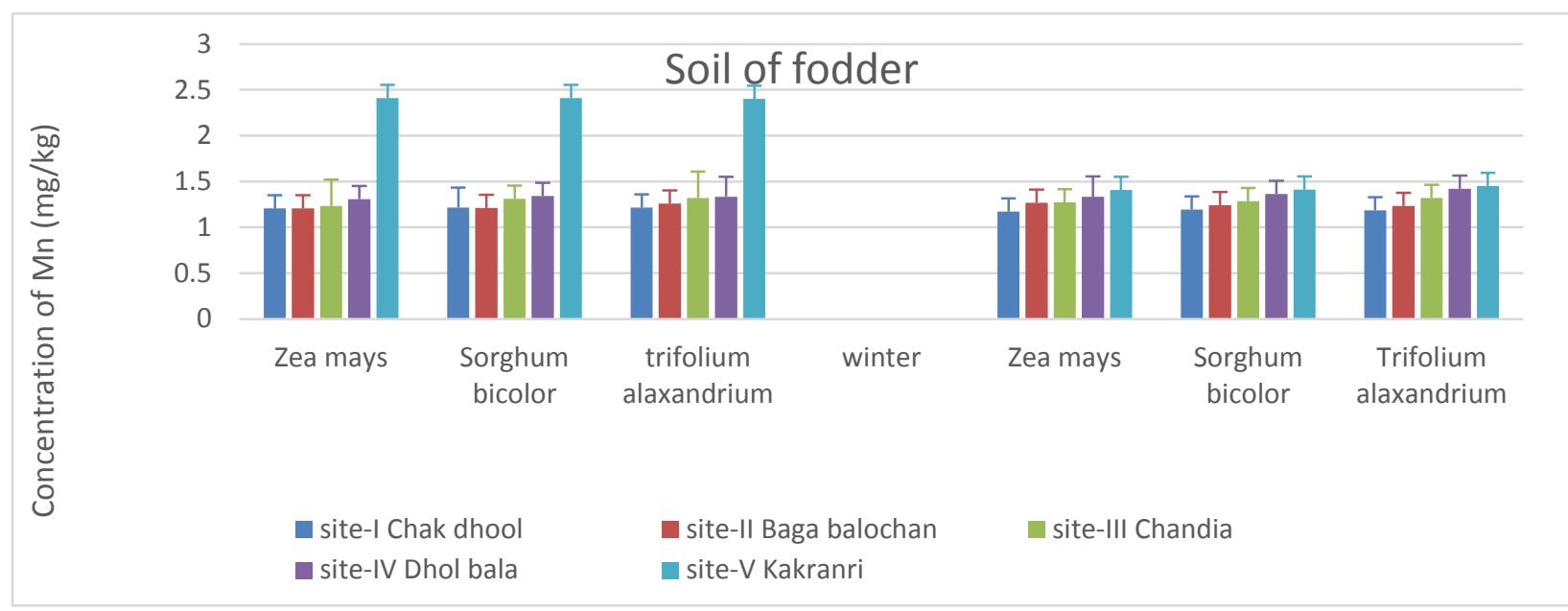

Figure 5. Fluctuations in mean concentration of $\mathrm{Mn}$ in soil at different sites during summer and winter season

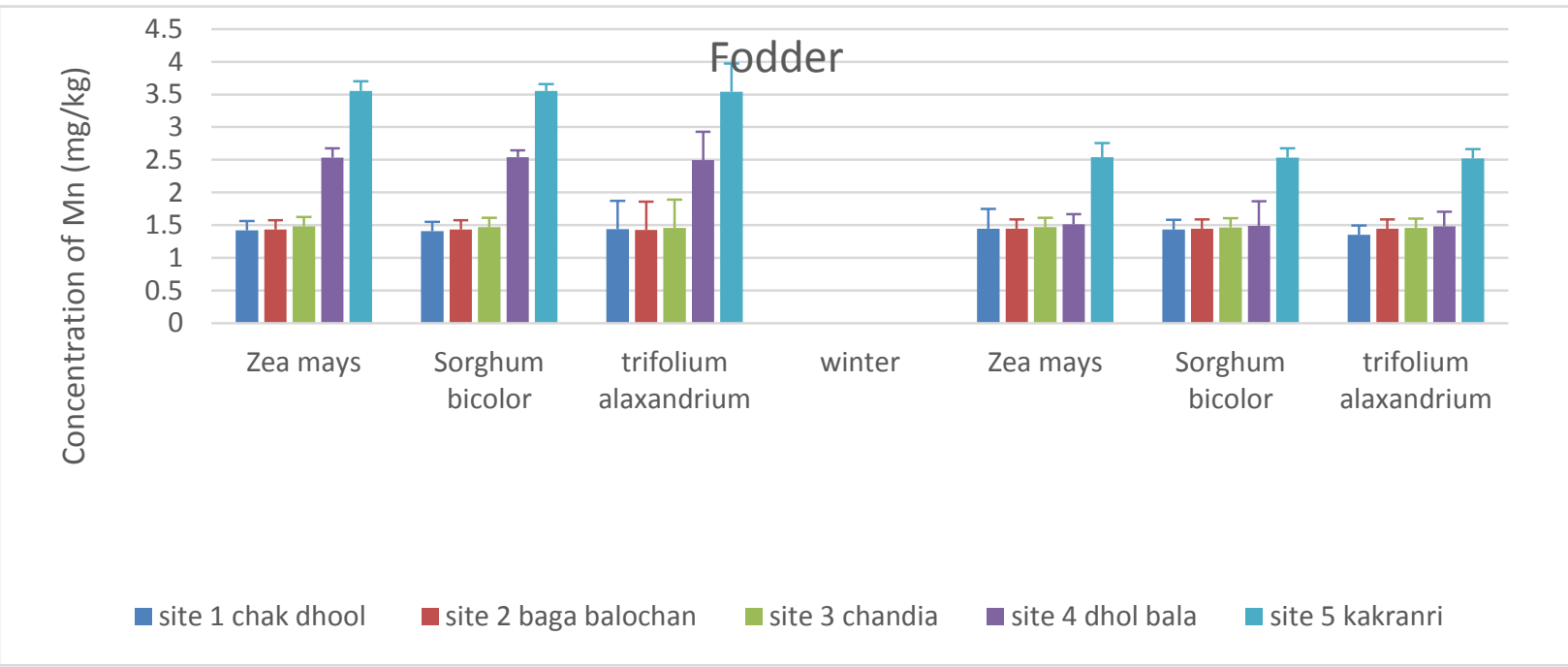

Figure 6. Fluctuations in mean concentration of $\mathrm{Mn}$ in fodder at different sites during summer and winter season 


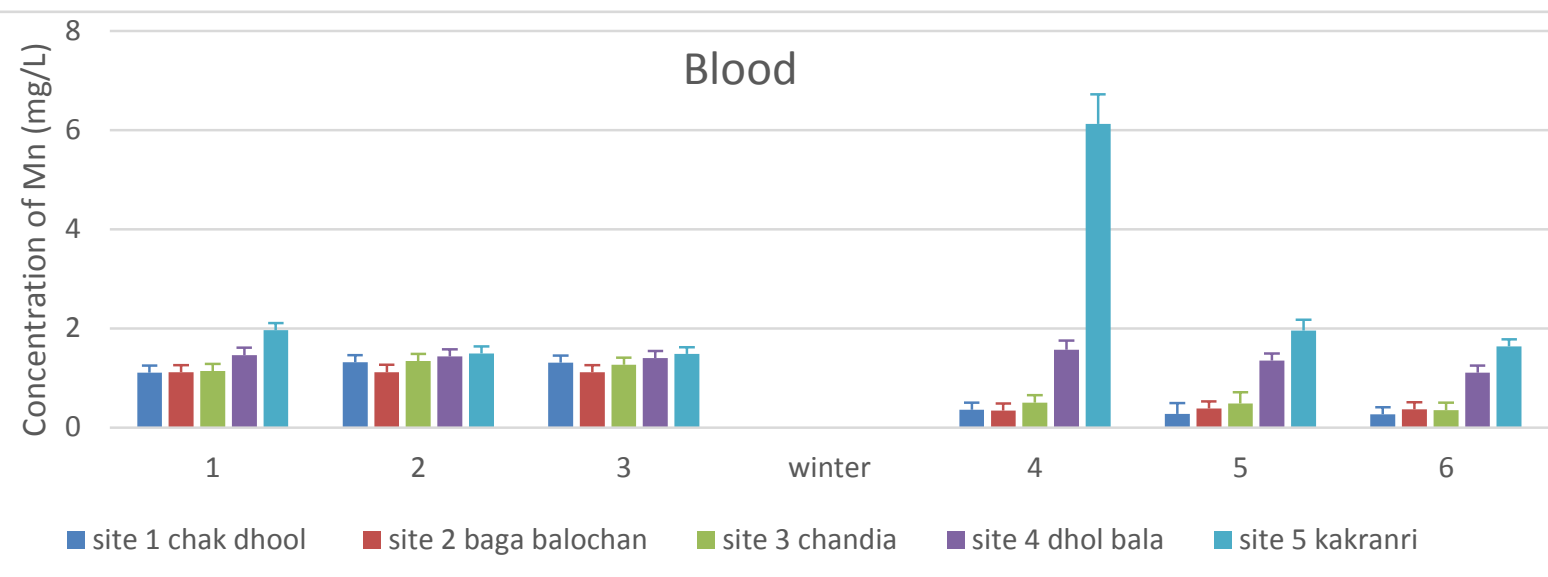

Figure 7. Fluctuations in mean concentration of Mn in blood samples at different sites during summer and winter season

Table 9. Correlation between soil-fodder-blood for Mn

\begin{tabular}{|c|c|c|c|c|c|c|}
\hline \multicolumn{7}{|c|}{ Correlation coefficient } \\
\hline & \multicolumn{2}{|c|}{ Z. mays } & \multicolumn{2}{c|}{ S. bicolor } & \multicolumn{2}{c|}{ T. alexandrinum } \\
\hline & Soil-fodder & Fodder-Blood & Soil-Fodder & $\begin{array}{c}\text { Fodder- } \\
\text { blood }\end{array}$ & $\begin{array}{c}\text { Soil- } \\
\text { fodder }\end{array}$ & $\begin{array}{c}\text { Fodder- } \\
\text { blood }\end{array}$ \\
\hline Summer & $0.999^{* *}$ & $0.925^{*}$ & $0.902^{*}$ & 0.651 & $0.900^{*}$ & 0.848 \\
\hline Winter & $0.885^{*}$ & $0.978^{* *}$ & 0.740 & 0.833 & 0.692 & 0.861 \\
\hline
\end{tabular}

**. Correlation is significant at the 0.01 level (2-tailed)

\section{Discussion}

Industrial development and human activities cause the $\mathrm{Cd}$ most prevalent pollutant in agriculture soil and soil plant system. Cadmium accumulation in the environment is presently turning into an essential reason for environmental pollution. Cadmium is mainly toxic chemical found in soil for both plant and animals [12]. In the present study, $\mathrm{Cd}$ values in soil samples ranged from $(0.60$ to $0.783 \mathrm{mg} / \mathrm{kg})$ in summer season and $(0.10$ to $0.233 \mathrm{mg} / \mathrm{kg}$ ) in winter season. Values were lower than permissible limit of $\mathrm{Cd}$ is $3 \mathrm{mg} / \mathrm{kg}$ according to FAO/WHO [21]. It can be easily taken up by roots and effect on biochemical, morphological, physiological activities of plants and impact negatively. It may cause death of plants. Relatively high $\mathrm{Cd}$ in fodder samples was noticed at site- $\mathrm{V}$ in summer 0.85 to $0.925 \mathrm{mg} / \mathrm{kg}$ higher than permissible limit $0.1 \mathrm{mg} / \mathrm{kg}$ according to WHO [20]. Cd is easily available to plants as its exchangeable capacity is higher and easily soluble in soil [22]. High Cd accumulation in the fodder samples studied in the present research may be due to this reason.

Cadmium has been considered as one of the main toxic metals that strive and act together with other essential metals such as Iron, Zinc and Copper, and bring shortages of these metals in organisms. In the present study, it was noted that blood samples collected at site- $\mathrm{V}$ in summer had more $\mathrm{Cd}$ values $(0.2125-0.70)$ than the samples collected in winter season (0.2017-0.2350).

Higher Mn values were found at site-V (2.402.41). All values were lower than recommended by FAO/WHO [21] as $46.75 \mathrm{mg} / \mathrm{kg}$. Sparks [23] and Ness \& Woolhouse [24] reported higher values as compared to present investigation. Mn takes part in photosynthesis in water splitting system in photosystem-II by providing electron Goussias et al. [25]. However, its 
higher values are hazardous for plants Migocka and Klobus [26]. Higher Mn values in fodder samples ranged from 3.5425 to 3.555 at site- $\mathrm{V}$ and lower values from 1.35 to 1.4416 at site I. Mn permissible limit given by FAO/WHO [21] is $200 \mathrm{mg} / \mathrm{kg}$. Present $\mathrm{Mn}$ results were below than suggested value indicating that plants are less contaminated. Higher Mn concentrations in blood samples of buffaloes were found at site-V (1.6350$6.130 \mathrm{mg} / \mathrm{kg}$ ) and lower values at site-I (0.2650-0.3575 mg/kg). Tolerable intake of Mn in buffaloes is between $0.5-5 \mathrm{mg} / \mathrm{kg}$ [27, 28]. All the samples contained lower value than suggested value except for winter blood at site-V.

The value of PLI higher than 1 showed that soil is contaminated and lower than 1 considered as unpolluted Harikumar et al. [29]. In present research all the values are lower than 1.

Differences in concentrations of $\mathrm{Cd}$ is due to binding of metal to plant roots, available metal soil, type of plants species, physiochemical [30, 31].

Bioconcentration factor indicates the level of toxicity in animals Cui et al. [19] higher value was observed for $Z$. mays and lower for S. bicolor.

Tolerable daily intake limit for $\mathrm{Cd}$ is $0.07 \mu \mathrm{g} / \mathrm{kg}$ and $0.5-5 \mu \mathrm{g} / \mathrm{kg}$ for $\mathrm{Mn}$ set by WHO [32]. Present studies showed the intake lower than TDI for both metals.

HRI values indicated the high values for both $\mathrm{Cd}$ and $\mathrm{Mn}$ that cause toxic effects on buffalo it is due to reason that in both seasons' livestock owners are more likely to graze their animals than harvesting on contaminated soils. Mn had highest values for health risk index.

Abundance of metals in soils than standard Hernandez et al. [33]. Lower values of EF for $\mathrm{Cd}$ and $\mathrm{Mn}$ indicate its high retention in soil. Present values were lower than Sherif et al. [34] for Cd.

\section{Conclusion}

This is the first study to find the heavy metal content in waste water irrigated soil in Tehsil Sahiwal of district Sargodha. Irrigation with waste water is common practice now a days. In this study Soil, Fodder and Blood sample showed a cooperative amount of metals, However it varied from site to site. Higher concentration were found at site- $\mathrm{V}$ and lower at site-I. All the values were within the range. Fodder samples of $\mathrm{Cd}$ showed higher values than permissible limit. Further research on contamination of fodder crops is required.

\section{Authors' contributions}

Conceived and designed the experiments: ZI Khan \& K Ahmad, Performed the experiments: M Ghazzal, M Sohail, P Akhter \& H Bashir, Analyzed the data: N Mehmood \& K Wajid, Contributed reagents/ materials/ analysis tools: $\mathrm{M}$ Nadeem \& M Akhtar, Wrote the paper: IS Malik, S Mahpara, A Ashfaq \& M Munir.

\section{References}

1. Qishlaqi A \& Moore F (2007). Statistical analysis of accumulation and sources of heavy metals occurrence in agricultural soils of Khoshk River Banks, Shiraz, Iran. Am Eurasian J Agric Environ Sci 2(5): 565-573.

2. Scott SH \& Loeb GE (1996). Mechanics of feline soleus: II Design and validation of a mathematical model. J Muscle Res Cell Motil 17(2): 221-233.

3. Voutsa D, Grimanis A \& Samara C (1996). Trace elements in vegetables grown in an industrial area in relation to soil and air particulate matter. Environ Pollut 94(3): 325-335.

4. Al-Jassir MS, Shaker A \& Khaliq MA (2005). Deposition of heavy metals on green leafy vegerables sold on roadsides of Riyadh City, Saudi Arabia. Bullet Environ Contamin Toxicol 75(5): 10201027.

5. Udosen ED, Udossien EI \& Ibok UJ (1990). Evaluation of some metals in 
the industrial wastes from a paint industry and their environment pollution implications. Niger J Technol Res 2: 7177.

6. Odukoya OO, Bamgobose O \& Arowolo TA (2000). Heavy metals in topsoil of Abeokuta dumpsites. Global J Pure Appl Sci 7: 467-472

7. Haluschak P, Eilers RG, Mills GF \& Grift S (1998). Status of selected trace elements in agricultural soils of southern Manitoba. Canada: Agriculture and Agri-Food Canada.

8. Nordberg GF, Fowler BA, Nordberg M \& Friberg L (2005). Handbook on the toxicology of metals.

9. Khan ZI, Safdar H, Ahmad K, Wajid K, Bashir H, Ugulu I \& Dogan Y (2019). Health risk assessment through determining bioaccumulation of iron in forages grown in soil irrigated with city effluent. Environ Sci Pollut Res 26(14): 14277-14286.

https://doi.org/10.1007/s11356-01904721-1.

10. Khan ZI, Safdar H, Ahmad K, Ugulu I, Wajid K, Bashir H \& Dogan Y (2018). Manganese bioaccumulation and translocation of in forages grown in soil irrigated with city effluent: an evaluation on health risk. Res J Pharm Biol Chem Sci 9(5):759-770.

11. Ahmad K, Wajid K, Khan ZI, Ugulu I, Memoona H, Sana M, Nawaz K, Malik IS, Bashir H \& Sher M (2019). Evaluation of potential toxic metals accumulation in wheat irrigated with wastewater. Bullet Environ Contam Toxicol 102(6): 822-828. https://doi.org/10.1007/s00128-01902605-1.

12. Ahmad K, Nawaz K, Khan ZI, Nadeem M, Wajid K et al (2018a). Effect of diverse regimes of irrigation on metals accumulation in wheat crop: an assessment-dire need of the day. Fresen Environ Bullet 27(2): 846-855.

13. Ahmad K, Kokab R, Khan ZI, Ashfaq A, Bashir H, Munir M et al (2018b). Assessment of heavy metals in wheat variety "Chagi-2" under short-term wastewater irrigation. Biologia (Pak) 64(1): 15-25.

14. Mapanda F, Mangwayana EN, Nyamangara J \& Giller KE (2005). The effects of long-term irrigation using water on heavy metal contents of soils under vegetables. Agric Ecosys Environ 107: 151-156.

15. Haiyan W \& Stuanes A (2003). Heavy metal pollution in air-water-soilplant system of Zhuzhou City, Hunan Province, China. Water Air Soil Pollut 147: 79-107.

16. Buat-Menard P \& Chesselet R (1979). Variable influence of the atmospheric flux on the trace metal chemistry of oceanic suspended matter. Earth Planet Sci Letr 42(3): 399-411.

17. Liu WH, Zhao JZ, Ouyang ZY, Soderlund L \& Liu GH (2005). Impacts of sewage irrigation on heavy metals distribution and contamination in Beijing, China. Environ Inter 31: 805812.

18. Sajjad K, Farooq R, Shahbaz S, Khan MA \& Sadique M (2009). Health risk assessment of heavy metals for population via consumption of vegetables. World Appl Sci J 6:16021606.

19. Cui YJ, Zhu YG, Zhai RH, Chen DY, Huang YZ, Qui Y \& Liang JZ (2004). Transfer of metals from near a smelter in Nanning, China. Environ Int 30(6): 785791.

20. WHO (1996). Toxicological evaluation of certain food additives and contaminants. 33rd Report of the Joint FAO/WHO Expert Committee on food additives, 
21. FAO/WHO (2001). Codex Alimentarius Commission. Food additive and contaminants. Joint FAO/ WHO Food Standards Programme, ALINORM 01/ 12A, pp 1-289.

22. Liu JG, Qian M, Cai GL, Yang JC \& Zhu QS (2007). Uptake and translocation of $\mathrm{Cd}$ in different rice cultivars and the relation with $\mathrm{Cd}$ accumulation in rice grain. J Hazard Mater 143: 443-447.

23. Sparks D (1995). Environmental soil chemistry. San Diego, Academic Press, pp 352.

24. Ness PJ \& Woolhouse HW (1980). RNA synthesis in Phaseolus chloroplasts. 1. Ribonucleic acid synthesis and senescing leaves. J Exp Bot 31: 223-233.

25. Goussias C, Boussac A \& Rutherford W (2002). Photosystem II and photosynthetic oxidation of water: an overview. Phil Trans R Soc Lond B 357: 1369-1381.

26. Migocka M \& Klobus G (2007). The properties of the $\mathrm{Mn}, \mathrm{Ni}$ and $\mathrm{Pb}$ transport operating at plasma membranes of cucumber roots. Physiol Plant 129: 578587.

27. USEPA (2002). Solid waste and emergency response. In: AGENCY, USEP.

28. WHO/FAO (2007). Joint FAO/WHO food standard programme codex Alimentarius commission 13th session. Report of the thirty-eight session of the codex committee on food hygiene. Houston, ALINORM 07/30/13.

29. Harikumar PS, Nasir UP, Mujeebu MP \& Rahma (2009). Distribution of heavy metals in the core sediments of a tropical wetland system. Int $J$ Environ $\mathrm{Sci}$ Technol 6(2): 225-232.

30. Toth T, Tomas J, Lazor P, Bajcan D \& Jomova D (2009). The transfer of metals from contaminated soils into agricultural plants in high Tatars region. Czech $J$ Food Sci 27: 390-393.

31. Bose S \& Bhattacharyya AK (2008). Heavy metal accumulation in wheat plant grown in soil amended with industrial sludge. Chemosphere 70: 1264-1272.

32. WHO (World Health Organization) (1994). Quality Directive of Potable Water, Geneva, second ed, pp. 197.

33. Hernandez LE, Carpena-Ruiz R \& Garate A (1996). Alterations in the mineral nutrition of pea seedlings exposed to cadmium. J Plant Nutr 19: 1581-1598.

34. Sherif SEA, El-Kholy MM \& Salem TM (2015). Risk assessment of trace elements toxicity through edible plants from irrigation canal at Giza Governorate, Egypt. Iranica J Energy Environ 6(1): 47-55. 